\title{
Effects of polyunsaturated fatty acids on hepatic PPAR $\alpha$ mRNA levels in the transition cow
}

\author{
M.F. Palin ${ }^{1}$ and H.V. Petit \\ Dairy and Swine Research and Development Centre, Agriculture and Agri-Food Canada \\ Lennoxville, Quebec, Canada J1M $1 Z 3$
}

\begin{abstract}
A total of 33 Holstein cows were fed one of three diets with different fatty acid composition: supplement with $85 \%$ saturated fatty acids (EB), supplement with $10 \%$ linseed (LI), and control with no added fat $(\mathrm{CO})$. Blood and liver samples were collected on week $-6,-2,+2$, and +4 relative to calving. Two weeks after calving, liver PPAR $\alpha$ mRNA levels were lower in cows fed EB compared to those that were fed CO. These results also showed that lower liver PPAR $\alpha$ mRNA levels are associated with lower plasma glucose concentration in the overall cow population $(n=33)$.
\end{abstract}

KEY WORDS: PPAR $\alpha$, mRNA, fatty acids, cow, liver

\section{INTRODUCTION}

During the transition period, cows are usually in negative energy balance and excessive lipid mobilization occurs to support maintenance and milk production. Body fat mobilization increases blood and hepatic nonesterified fatty acids (NEFA) concentrations, which can lead to the development of fatty liver (Drackley, 1999). Supplemental fat and oils can be added to increase dietary energy density and thus to decrease the duration and magnitude of negative energy status. Mechanisms underlying the adaptive changes induced by dietary fat on liver metabolism remain unclear, but various studies point towards a group of nuclear hormones, termed peroxisome proliferator-activated receptors (PPARs) (Smith, 2002). Among these receptors, PPAR $\alpha$ is highly produced in the liver and can regulate the expression of various genes known to be involved in hepatic lipid metabolism. Mice lacking functional PPAR $\alpha$ shows enhanced accumulation of lipid droplets in the liver as well as impaired expression of several genes related to mitochondrial

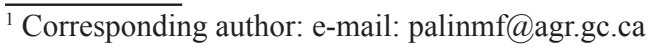


and peroxisomal ß-oxidation (Kersten et al., 1999). The objective of the present study was to verify if hepatic PPAR $\alpha$ mRNA levels can be modulated according to the type of fatty acids fed to transition cows.

\section{MATERIAL AND METHODS}

\section{Animals and treatments}

Thirty-three cows were fed one of three different diets based on a mixture of grass and maize silages. Diets varied in fat composition: control with no added fat (CO), supplemented with $85 \%$ saturated fatty acids (EB), and supplemented with $10 \%$ linseed (LI). Cows received the experimental diets from six weeks before parturition up to four weeks of lactation.

\section{Blood sample analyses}

Blood samples were collected on weeks $-6,-2,+2$, and +4 relative to calving and analysed for NEFA, \$-hydroxybutyrate and glucose. Fatty acid composition was also measured in plasma samples by gas chromatography.

\section{Liver samples analyses}

Liver biopsies were taken on the same weeks $(-6,-2,+2$ and +4$)$. Total RNA was extracted from liver biopsy samples using the TRIzol Reagent (Gibco-BRL). PPAR $\alpha$ mRNA levels were measured by real-time PCR using the SYBRGreen Master Mix (PE Applied BioSystems). Amplification, detection, and data analyses were performed with an ABI 7700 Prism Sequence Detector (PE Applied BioSystems). Liver biopsies were also taken to determine fatty acid composition by gas chromatography.

\section{Statistical analyses}

Data were analysed with the mixed procedure of the SAS Institute using dietary treatment $(\mathrm{CO}, \mathrm{EB}$ or $\mathrm{LI})$ and time of treatment $(-6,-2,+2$, and +4$)$ as fixed effects. Correlation analyses between PPAR $\alpha$ mRNA levels and fatty acid composition and plasma metabolite concentrations were calculated using the PROC CORR procedure of SAS (1999). Differences were considered significant at $\mathrm{P}<0.05$ and a tendency at $0.05<\mathrm{P}<0.10$.

\section{RESULTS}

Effects of dietary treatment and time relative to calving on PPAR $\alpha$ mRA levels in the liver

Using real-time PCR analyses, PPAR $\alpha$ mRNA levels were detected in liver biopsies. Two weeks after calving, PPAR $\alpha$ mRNA levels were lower in cows fed 
EB compared to those that were fed $\mathrm{CO}(\mathrm{P}<0.05)$. This treatment effect was not present at any other time $(\mathrm{P}>0.10$, data not shown).

Associations between plasma fatty acids and PPAR $\alpha$ mRA levels in the liver

Cows that received $10 \%$ linseed showed a negative correlation between PPAR $\alpha$ mRNA levels in the liver and plasma eicosapentanoic acid (EPA) percentage on week 4 after calving $(\mathrm{r}=-0.091, \mathrm{P}<0.01$; Figure 1$)$.

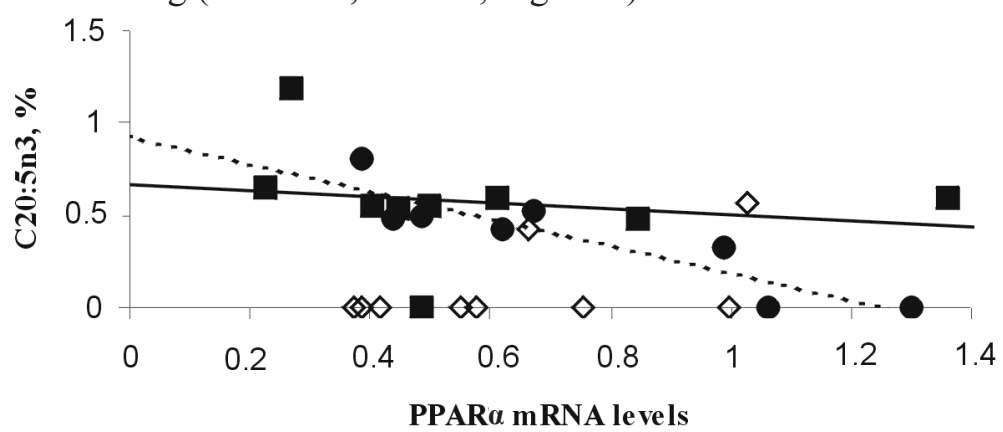

Figure 1. Association between PPAR $\alpha$ mRNA levels in the liver and plasma eicosapentanoic acid (C20:5n3) (percentage of total fatty acids) on wk 4 after calving. ...•..., cows fed LI diet;

cows fed EB diet; $\diamond$, control (with no added fat)

Associations between plasma glucose concentration and PPAR $\mathrm{mRNA}$ levels in the liver

A tendency was observed between plasma glucose concentration and PPAR $\alpha$ mRNA levels $(\mathrm{r}=0.62, \mathrm{P}=0.10)$ in liver biopsy from cows treated with $10 \%$ linseed on wk 2 after calving (Figure 2). In the overall cow population $(\mathrm{n}=33)$ and at the same time period, an association was also observed between plasma glucose concentration and PPAR $\alpha$ mRNA levels $(r=0.46, \mathrm{P}<0.05$; Figure 2).

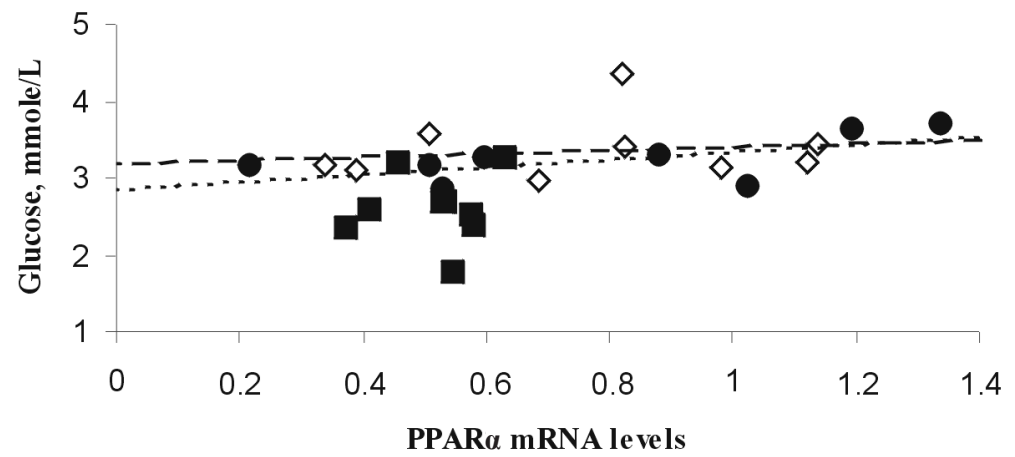

Figure 2. Association between PPAR $\alpha$ mRNA levels in the liver and plasma glucose concentration two weeks after calving. ....•.... , cows fed LI diet; - ., cows fed EB diet; ---- $\vee----$, control (with no added fat) 


\section{DISCUSSION}

It is well known that PPARs can regulate fatty acid oxidation and storage according to fluctuations in dietary fat intake (Smith, 2002). More precisely, PPAR $\alpha$ regulates pathways of fatty acid oxidation, whereas PPAR $\gamma$ modifies fatty acid synthesis and storage. Thus, the lower PPAR $\alpha$ mRNA levels observed in cows fed EB diet on wk 2 after calving may reflect lower fatty acid oxidation capacity. In cows fed 10\% linseed, the negative association found between plasma concentrations of EPA and PPAR $\alpha$ mRNA levels in the liver was unexpected since EPA is a known peroxisome proliferator (Froyland et al., 1997). In our study, we observed that lower concentrations of plasma glucose were associated with lower PPAR $\alpha$ mRNA levels in liver tissue. It was reported that PPAR $\alpha$-null mice fasted for $24 \mathrm{~h}$ exhibited severe hypoglycaemia (Kertsen et al., 1999). As it was demonstrated in a recent study, we may hypothesize that lower liver PPAR $\alpha$ mRNA levels are associated with lower gluconeogenesis and/or partitioning of newly produced glucose 6-phosphate towards hepatic glycogen stores (Bandsma et al., 2004).

\section{CONCLUSIONS}

Hepatic PPAR $\alpha$ mRNA levels are lower when high saturated fatty acids diet (EB) is fed to transition Holstein cows. We also report that lower PPAR $\alpha$ mRNA levels are associated with lower plasma glucose concentration. Thus, it will be of interest to verify if these low concentrations of circulating glucose are associated with higher liver glycogen concentrations.

\section{REFERENCES}

Bandsma R.H., Van Dijk T.H., Harmsel A.T., Kok T., Reijngoud D.J., Staels B., Kuipers F., 2004. Hepatic de novo synthesis of glucose 6-phosphate is not affected in peroxisome proliferatoractivated receptor alpha-deficient mice but is preferentially directed toward hepatic glycogen stores after a short term fast. J. Biol. Chem. 279, 8930-8937

Drackley J., 1999. Biology of dairy cows during the transition period: the final frontier? J. Dairy Sci. 82, 2259-2273

Froyland L., Madsen L., Vaagenes H., Totland G.K., Auwerx J., Kryvi H., Staels B., Berge R.K., 1997. Motochondrion is the principal target for nutritional and pharmacological control of triglyceride metabolism. J. Lipid Res. 38, 1851-1858

Kersten S., Saydoux J., Peters J.M., Gonzalez F.J., Desvergne B., Whali W., 1999. Peroxisome proliferators-activated receptor alpha mediates the adaptive response to fasting. J. Clin. Invest. $103,1489-1498$

SAS Institute Inc., 1999. SAS User' Guide: Statistics, Ver. 8.01 Edition. SAS Inst., Cary, NC

Smith S.A., 2002. Peroxisome proliferators-activated receptors and the regulation of mammalian lipid metabolism. Biochem. Soc. Trans. 30, 1086-1090 